\title{
Effects of Ovarian Steroids on Osteoblast Viability and Mineralization
}

\author{
L. F. C. Brancaglião ${ }^{1,2}$, A. L. O. Bonfá2 ${ }^{2}$ J. E. S. Lemos ${ }^{1}$, N. F. Rocha ${ }^{1}$, \\ V. M. Gonçalves ${ }^{1}$ and L. H. Montrezor ${ }^{1,2^{2}}$ \\ ${ }^{1}$ Department of Biological Science and Health - Medicine - University of Araraquara (UNIARA), \\ Araraquara, $S P$, Brazil. \\ ${ }^{2}$ Medical Chemistry and Regenerative Medicine Group - QUIMMERA - UNIARA, Araraquara, \\ SP, Brazil.
}

Authors' contributions

This work was carried out in collaboration between all authors. Author LHM designed the study, performed the statistical analysis, wrote the protocol and wrote the first draft of the manuscript. Authors LFCB, JESL, ALOB and LHM managed the analyses of the study. Authors LFCB, JESL, NFR and VMG managed the literature searches. All authors read and approved the final manuscript.

Article Information

DOI: $10.9734 / \mathrm{AJOB} / 2017 / 34036$

Editor(s):

(1) Xing Li, Division of Biomedical Statistics and Informatics, Department of Health Sciences Research, Mayo Clinic College of Medicine, USA. Reviewers:

(1) Ayhan Goktepe, Selcuk University, Konya, Turkey. (2) Praveen Kumar Pandey, Guru Gobind Singh Indraprastha University, India. (3) Giovanni Messina, University of Foggia, Italy. Complete Peer review History: http://www.sciencedomain.org/review-history/19242

Original Research Article

Received $10^{\text {th }}$ May 2017

Accepted $24^{\text {th }}$ May 2017

Published $30^{\text {th }}$ May 2017

\section{ABSTRACT}

Understanding the interactions between bone metabolism and ovarian and plasma changes induced by polycystic ovary syndrome (PCOS) is essential for the comprehension of the pathophysiological mechanisms involving these organs. Ovarian steroids are associated with activities related to bone synthesis and resorption. Knowledge of the effects of the main ovarian steroids on the viability of osteoblasts in culture, mimicking the conditions of PCOS, can assist in understanding the functions of the cells in this endocrine disease that affects more than $10 \%$ of women of reproductive age. This work evaluated the viability of undifferentiated and differentiated osteoblasts in an osteogenic medium, together with phosphatase activity and mineralization of the extracellular matrix. The cells were cultured for different periods of time in the presence of varied concentrations of progesterone, testosterone, estradiol, and the combination of all three hormones.

*Corresponding author: E-mail: Ihmontrezor@uniara.com.br; 
The influence of the presence of fetal bovine serum in the culture medium was also determined. The results suggested that the culture technique employed could be used for in vitro studies of the effects of polycystic ovary syndrome on osteoblastic activities, before and after cell differentiation.

Keywords: Cell culture; osteoblast; polycystic ovary syndrome; cell viability; ovarian steroids.

\section{INTRODUCTION}

Bone is a metabolically active tissue whose constant remodeling is dependent on the activity of osteoclasts for bone resorption and osteoblasts for synthesis of the bone matrix $[1,2,3]$. Bone remodeling involves the continuous removal of bone followed by the synthesis of new bone matrix and subsequent mineralization. It is required for calcium homeostasis and that repair of injuries associated with stress, age, and enodcrine interactions $[4,5,6]$.

The sex steroids act on bone metabolism. Androgens are importante in the physiological mechanisms that control bone and muscle activities in women, exerting direct and/or indirect action on bone remodeling. Direct actions are a result of the binding of testosterone $(T)$ to androgen nuclear receptors of bone cells. Indirect actions involve the conversion of $\mathrm{T}$ to estradiol (E2). This conversion requires the activity of the enzyme CYP19A1 (Cytochrome P450 19A1), present in the mitochondrial matrix of bone cells, which aromatizes androstenedione and $\mathrm{T}$ to estradiol [7]. Clinical evidence has found increased bone mass as a result of the actions of androgens in women with hirsutism, polycystic ovarian disease, and androgen-secreting ovarian tumor $[8,9,10]$. In addition, androgen deficiency may cause reductions in trabecular and cortical bone density [11].

Estrogen deficiency observed in women at menopause or in case of ovarian failure stimulates the activity of osteoclasts, causing increased bone resorption and decreased bone mineral density. Early estrogen therapy can minimize vertebral damage by inhibiting the resorption, thereby reducing the number and activity of osteoclasts [12]. Estrogens and androgens decrease the number of bone remodeling cycles, regulating transcription of the genes responsible for osteoclastogenesis, replication, and differentiation of mesenchymal cells [13].

The functional role of progestogens in the prevention of bone loss is less well understood than the roles of androgens and estrogens. Progesterone (P4) receptors have been identified in osteoclasts and osteoblasts from rats and humans [14]; however, it is not clear whether the activities of P4 in bone are direct or indirect [7]. The use of cyclic progestin prevents bone loss in women with premenopausal amenorrhea or subclinical ovulatory disorders [15].

Polycystic ovary syndrome (PCOS) is a heterogeneous endocrinopathy with adverse metabolic characteristics such as insulin resistance, hyperinsulinemia [16,17], obesity, anovulation, hyperandrogenism and abnormal ovarian morphology $[17,18,19]$. Approximately $5-10 \%$ of women of reproductive age are affected by PCOS [20], and between $38 \%$ and $88 \%$ of these women are overweight or obese $[21,22,23,24]$. The clinical and biochemical conditions of PCOS can be affected by obesity and are related to various metabolic events such as insulin resistance accompanied by compensatory hyperinsulinemia, increasing the risk of developing type 2 diabetes between 5-and 8-fold in women with PCOS. Furthermore, the risks of developing hypertension and coronary heart disease are also higher in obese women with PCOS [5,21,23], while oxidative stress, dyslipidemia, inflammation and fibrinolysis increase the risk of stroke in women with PCOS [25]. It is estimated that the prevalence of the risk factors for each of these diseases is approximately two times higher in women with PCOS compared to women who do not have the syndrome [26].

Current treatments for PCOS are not restricted to reproductive approaches; they also include the promotion of cardiovascular health and disease prevention measures, with non-pharmacological measures including nutritional counseling and regular physical activity. Although the effects of long-term treatment strategies for PCOS have not been fully elucidated [27], lifestyle and dietary changes [28,29], regular physical exercise and weight loss [29,30,31,32], cessation of smoking, stress management, and moderate alcohol consumption [29] have been identified as important steps in the treatment of PCOS. 
Women with PCOS have higher incidences of excess weight, obesity, dyslipidemia, hyperinsulinemia, and type II diabetes, and consequently present greater risk of cardiovascular disease and bone disorders. Furthermore, modification of bone metabolism due to hyperandrogenemia and insulin resistance can lead to changes in the composition of structures ranging from skeletal muscle to adipose tissue. Our laboratory is working on induced PCOS in animal models [33] in order to investigate the interrelationships among this important ovarian endocrine disease and adipose, skeletal muscle, and bone tissues [34]. The aim of this study was to use a cell culture model mimicking polycystic ovary syndrome to study the effects of this endocrinopathy on osteoblast cell viability, alkaline phosphatase activity, and extracellular matrix mineralization.

\section{MATERIALS AND METHODS}

\subsection{Cell Culture}

The OSTEO-1 osteoblast line [34], obtained from ICB-USP, was used for the cell cultures. Our laboratory has already used these cells in more than ten experiments. Six separate cell cultures were used in the present study. Each well of 96well culture plate was inoculated with $5 \times 10^{3}$ cells in $100 \mu \mathrm{L}$ of modified Eagle's medium (Sigma-Aldrich, St. Louis, MO, USA), without or with supplementation using $10 \%$ fetal bovine serum (FBS) (Sigma-Aldrich, St. Louis, MO, USA), penicillin (100 U/mL), and streptomycin (100 $\mu \mathrm{g} / \mathrm{mL}$ ) (Sigma-Aldrich, St. Louis, MO, USA). The cells were maintained at $37^{\circ} \mathrm{C}$ under a humid atmosphere of $5 \% \mathrm{CO}_{2}$ and $95 \%$ air for 12 h, $24 \mathrm{~h}, 36 \mathrm{~h}$ (data not shown), $48 \mathrm{~h}$, and $72 \mathrm{~h}$ [35]. Tests were performed to determine the optimum culture time, which was set at $72 \mathrm{~h}$. The medium was replaced every $72 \mathrm{~h}$ and stored at $20^{\circ} \mathrm{C}$ for later analysis of alkaline phosphatase.

\subsection{Steroid Hormones}

Progesterone, testosterone, and estradiol (Sigma-Aldrich, St. Louis, MO, USA) were used at different concentrations: control (without hormones), $10^{-8} \mathrm{M}$ and $10^{-7} \mathrm{M}$ (mimicking normal plasma concentrations in adult female rats), and $10^{-6} \mathrm{M}$ and $10^{-5} \mathrm{M}$ (mimicking plasma concentrations in adult female rats with induced PCOS) [33]. The steroids were added both independently, and in combination (all in the same well) to the wells of culture plates containing $5 \times 10^{3}$ cells and $100 \mu \mathrm{L}$ of culture medium, and the plates were maintained under the culture conditions described previously.

\subsection{Steroid Hormones and Osteogenic Differentiation}

Differentiation was induced using an osteogenic medium, following the procedures outlined by Maniatopoulos et al. [36]. Eagle's medium was supplemented with $10 \%$ FBS, $50 \mu \mathrm{g} / \mathrm{mL}$ ascorbic acid (Sigma-Aldrich, St. Louis, MO, USA), $10^{-8} \mathrm{M}$ dexamethasone (Sigma-Aldrich, St. Louis, MO, USA), and $10 \mathrm{mM} \beta$-glycerophosphate (SigmaAldrich, St. Louis, MO, USA). Each well of 24well culture plates was inoculated with $5 \times 10^{5}$ cells in $1000 \mu \mathrm{L}$ of medium. The steroid hormones (P4, T, and E2) were added (alone or in combination) to the culture medium at the same concentrations described above: control (without hormones), $10^{-8} \mathrm{M}, 10^{-7} \mathrm{M}, 10^{-6} \mathrm{M}$, and $10^{-5} \mathrm{M}$. The plates were incubated at $37^{\circ} \mathrm{C}$ under a humidified atmosphere of $5 \% \mathrm{CO}_{2}$ and $95 \%$ air for 7 days and 14 days. Day 0 (zero) was taken to be the day on which the cells showed confluence (between $80 \%$ and $100 \%$ ) at the bottom of the wells of the culture plate. The medium was replaced every $72 \mathrm{~h}$ and stored at $20^{\circ} \mathrm{C}$ for later analysis of alkaline phosphatase.

\subsection{Cell Viability}

Cell viability was assessed after $12 \mathrm{~h}, 24 \mathrm{~h}, 36 \mathrm{~h}$ (data not shown), $48 \mathrm{~h}$, and $72 \mathrm{~h}$ of incubation. The MTT colorimetric assay was used, in which the reduction of 3- (4,5-dimethylthiazol-2-yl)-2,5diphenyltetrazolium bromide (Sigma-Aldrich, St. Louis, MO, USA) produces formazan (a blue crystalline product), by the action of mitochondrial dehydrogenase in viable cells. The quantity of these product is directly proportional to the blue coloration, enabling estimation of the number of mitochondria and consequently, the number of viable cells in the culture, hence providing and indirect measure of cell viability. After removal of the culture medium from the wells, $50 \mu \mathrm{L}$ of MTT $(0.5 \mathrm{mg} / \mathrm{mL})$ was added to each well and the plate was incubated for $4 \mathrm{~h}$ at $37^{\circ} \mathrm{C}$ in $5 \% \mathrm{CO}_{2}$. Subsequently, $100 \mu \mathrm{L}$ of acid isopropanol was added to each well in order to fully solubilize of the precipitate formed, and the absorbance of the solution was measured at 570 $\mathrm{nm}$ [37] using a microplate reader (Polaris, Celer Biotecnologia, Belo Horizonte, MG, Brazil). The optical density (OD) was expressed as cell viability using the index: cell viability (\%) = $(100 \mathrm{x}) /$ control. The value for the control was taken as $100 \%$, with values above and below 
$100 \%$ indicating increased and decreased cell viability, respectively.

\subsection{Alkaline Phosphatase Activity}

Alkaline phosphatase activity was determined from measurements of the release of thymolphthalein from thymolphthalein monophosphate, using a commercial kit (Labtest Diagnostica, Belo Horizonte, MG, Brazil). Aliquots of $50 \mu \mathrm{L}$ of the culture medium were used. Absorbance was measured at $590 \mathrm{~nm}$ and the ALP activity was calculated based on the value for a standard.

\subsection{Detection and Quantification of Biological Mineralization}

The method described by Gregory et al. [38] was used to detect extracellular matrix mineralization. Briefly, at the end of days 7 and 14 of the culture, plate wells containing osteogenic cells were washed with cold PBS (Sigma-Aldrich, St. Louis, MO, USA) and filled with formaldehyde (10\% v/v) (Merck, Kenilworth, NJ, USA) for $30 \mathrm{~min}$. Subsequently, the wells were washed with deionized water and $1 \mathrm{~mL}$ of Alizarin Red (Sigma-Aldrich, St. Louis, MO, USA) solution was added. After $30 \mathrm{~min}$, the excess Alizarin Red solution was removed, the wells were washed with water, and the plates were kept at room temperature for the wells to dry.

Quantification of extracellular matrix mineraliztion was performed by adding $450 \mu \mathrm{L}$ of acetic acid solution $(10 \% \mathrm{v} / \mathrm{v})$ to each well that had been previously stained with Alizarin Red. The plates were kept on a shaker for $30 \mathrm{~min}$ at room temperature, after which, $400 \mu \mathrm{L}$ aliquots of the contents of each well were transferred to Eppendorf tubes, followed by addition of $150 \mu \mathrm{L}$ of $\mathrm{NH}_{4} \mathrm{OH}$. Finally, the contents of the Eppendorf tubes were transferred to 96-well plates and the absorbances were measured at $405 \mathrm{~nm}$ using a microplate reader [38].

\subsection{Statistical Analysis}

The Sigma Stat software (Systat Software, Point Richmond, CA, USA) was used for statistical analyses. Means and standard deviation were calculated for each experimental variable and statistical significance was set up $p<0.05$. Data collected were compared by means of one-way repeated measure analysis of variance (ANOVA), follwed by Turkey's multiple comparisions pos hoc test.

\section{RESULTS}

\subsection{Effects of Fetal Bovine Serum and Culture Time on Viability of the OSTEO-1 Cells}

The viability of the OSTEO-1 osteoblasts (Fig. 1) cultured for $72 \mathrm{~h}$ was higher than that of the control group $(0 \mathrm{~h})$, in both the absence and presence of FBS. The viability of cells cultured for $72 \mathrm{~h}$ in the presence of FBS was higher than the cell viability of cells grown without serum for the same culture time.

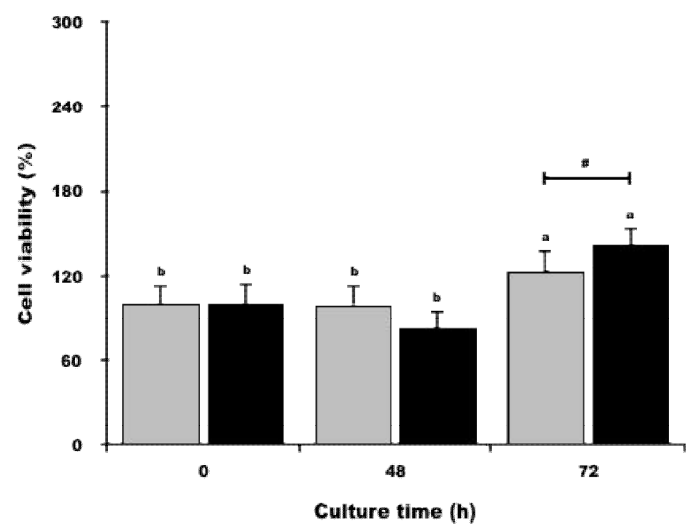

Fig. 1. Effects of absence (gray bars) and presence (black bars) of bovine fetal serum on viability of osteoblast - OSTEO-1 cultured until 72 hours

Results are represented as means +/- SEM. ( $n=6$ independent cultures). Different superscript lowercase letters indicate differences within the group among the times; \# indicate differences among the groups. $p<0.05$

\subsection{Effects of Steroids P4, T, and E2 on Viability of the OSTEO-1 Cells Cultured for $72 \mathrm{~h}$}

Higher viability was shown by the cells maintained in culture for $72 \mathrm{~h}$ without FBS in the presence of progesterone (Fig. 2A) at concentrations of $10^{-7} \mathrm{M}$ and $10^{-6} \mathrm{M}$, while lower viability was observed in the presence of $\mathrm{P} 4$ at $10^{-5} \mathrm{M}$. In the presence of $10 \%$ FBS, cell viability was higher at P4 concentrations of $10^{-8} \mathrm{M}$ and $10^{-7} \mathrm{M}$. The lowest cell viability was observed for cells cultured with P4 at $10^{-6} \mathrm{M}$. In comparison of the groups with and without serum, at P4 concentrations of $10^{-8} \mathrm{M}, 10^{-5} \mathrm{M}$, and $0 \mathrm{M}$ (control), higher viability was found for the cells cultured in the presence of serum. At a P4 concentration of $10^{-6} \mathrm{M}$, the serum-free cell group showed the highest cell viability. 
The viability of the OSTEO- 1 cells maintained in culture for $72 \mathrm{~h}$ in the presence of testosterone (Fig. 2B) and absence of serum varied according to the concentration used. The highest viability was observed with $10^{-7} \mathrm{M}$ of $\mathrm{T}$ and the lowest cell viability was observed for cells cultured with $10^{-5}$ $\mathrm{M}$ of $\mathrm{T}$. When the cells were cultured in the presence of $10 \%$ FBS, the cell viability decreased with increasing $T$ concentrations. Comparing the groups with and without serum, the serum groups showed higher viability, compared to those cultured without serum.

The effect of estradiol on the viability of the OSTEO- 1 cells is shown in Fig. 2C. In the absence of $10 \%$ FBS, the highest and lowest cell viabilities were observed in the presence of $10^{-5}$ $\mathrm{M}$ and $10^{-8} \mathrm{M}$ of E2, respectively. In the presence of $10 \%$ serum, the highest and lowest cell viabilities were observed in the presence of $10^{-6}$ $M$ and $10^{-8} M$ of E2, respectively. Comparing the groups with and without $10 \%$ FBS, viability was greater for the control group and the serum groups at concentrations of $10^{-7} \mathrm{M}$ and $10^{-6} \mathrm{M}$ of
E2. In the case of the groups treated with $10^{-5} \mathrm{M}$ of estradiol, the serum-free group presented the highest viability.

The viability of the OSTEO-1 cells cultivated for $72 \mathrm{~h}$ was also influenced by addition of all the steroids together (Fig. 2D). In the absence of $10 \%$ fetal bovine serum, cell viability was highest in the presence of all the hormones at concentrations of $10^{-7} \mathrm{M}$ and lowest with all the hormones at concentrations of $10^{-5} \mathrm{M}$. When fetal bovine serum was added to the culture medium, higher viabilities were observed in the cultures with hormone concentrations of $10^{-8} \mathrm{M}$ and $10^{-7} \mathrm{M}$, while lower cell viability was observed in the presence of $10^{-5} \mathrm{M}$ of the hormones. Comparison of the groups with and without FBS showed that cell viability was higher in the groups with serum in the case of the control group, and the cells cultured using hormone concentrations of $10^{-8} \mathrm{M}$ and $10^{-6} \mathrm{M}$. At hormone concentrations of $10^{-7} \mathrm{M}$ and $10^{-5} \mathrm{M}$, the viability was higher for the cells cultured without serum.

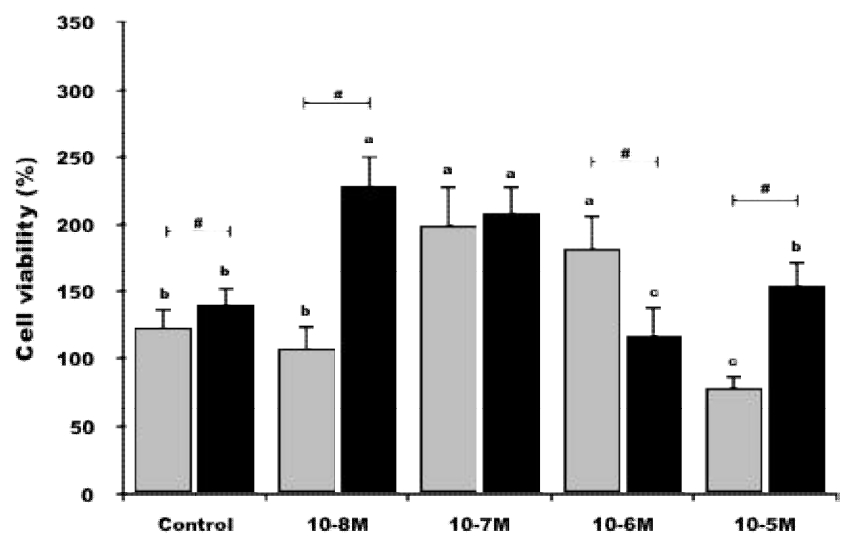

(B)

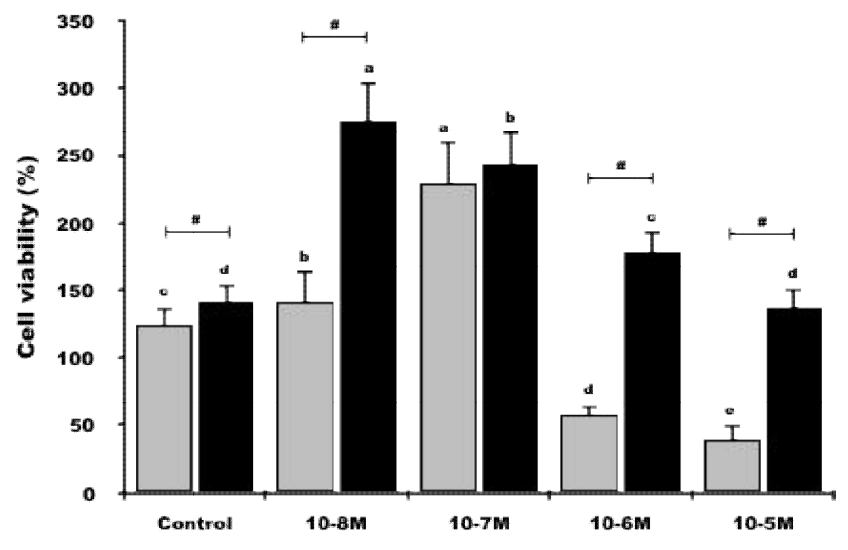


(C)

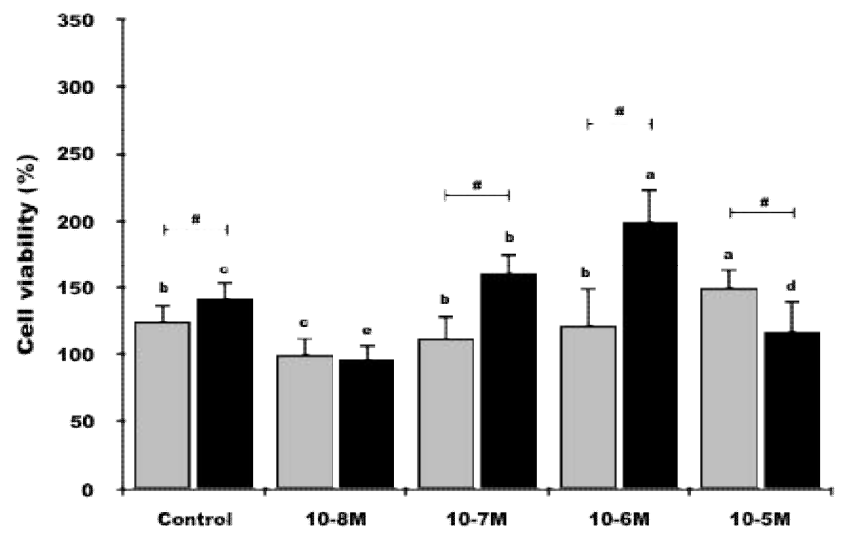

(D)

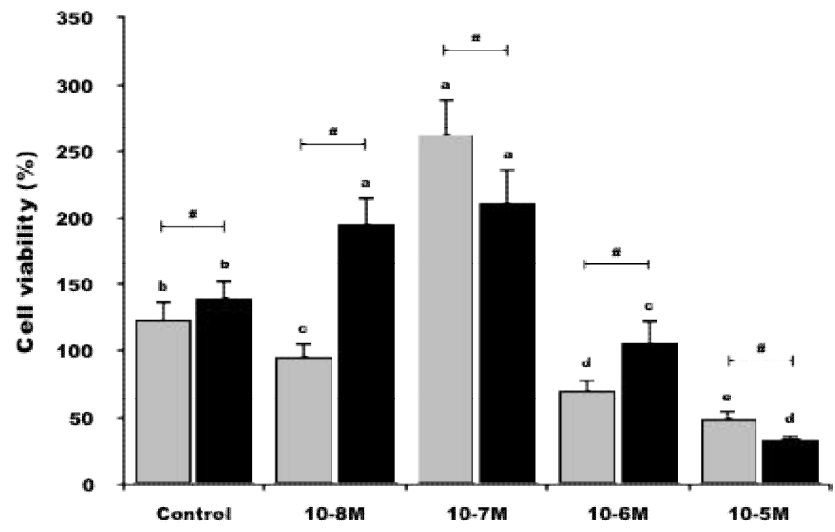

Fig. 2. Effects of different concentrations ( 0 (control), $10^{-8} \mathrm{M}, 10^{-7} \mathrm{M}, 10^{-6} \mathrm{M}$ and $10^{-5} \mathrm{M}$ ) of progesterone (A), testosterone (B), estradiol (C) and all hormones together (D) on osteoblast - OSTEO-1 viability cultured in the absence (gray bars) and presence (black bars) of bovine fetal serum for 72 hours

Results are represented as means +/- SEM. ( $n=6$ independent cultures). Different superscript lowercase letters indicate differences within the group among the concentrations; \# indicate differences among the groups. $p<0.05$

\subsection{Effects of Culture Time and the P4, T, and E2 Steroid Hormones on Viability of Osteoblasts Cultured in Osteogenic Medium}

For the culture time employed here, the cells cultured in osteogenic medium for 14 days showed lower viability than those cultured for 0 and 7 days (Fig. 3). The viability of osteoblasts cultured for 7 days and 14 days was influenced by progesterone (Fig. 4A). For cells cultured for 7 days, greater viability was observed in the presence of the highest concentration $\left(10^{-5} \mathrm{M}\right)$ of $\mathrm{P} 4$, while lower viabilities were observed for cells cultured at concentrations of $10^{-8} \mathrm{M}, 10^{-7} \mathrm{M}$, and $10^{-6} \mathrm{M}$ of P4. When the cells were cultured for 14 days, all P4 concentrations used reduced the cell viability, with the concentration of $10^{-6} \mathrm{M}$ resulting in the greatest reduction.

When the osteoblasts were cultured for 7 days in the presence of testosterone (Fig. 4B), hormone concentrations of $10^{-7} \mathrm{M}, 10^{-6} \mathrm{M}$, and $10^{-5} \mathrm{M}$ resulted in decreased cell viability. All $T$ concentrations used decreased the viability of osteoblasts cultured for 14 days, and the lowest viability was observed in the presence of $10^{-5} \mathrm{M}$ of the hormone.

When the cells were cultured with estradiol for 7 days, the highest and lowest viabilities were foud for concentrations of $10^{-5} \mathrm{M}$ and $10^{-6} \mathrm{M}$, respectively (Fig. 4C). Lower viabilities were obtained for cells cultured for 14 days with 
estradiol at concentrations at $10^{-7} \mathrm{M}, 10^{-6} \mathrm{M}$, and $10^{-5} \mathrm{M}$.

When the combined hormones were added to the osteogenic medium (Fig. 4D), concentrations of $10^{-7} \mathrm{M}, 10^{-6} \mathrm{M}$, and $10^{-5} \mathrm{M}$ decreased the viability of cells cultured for 7 days, while cells cultured for 14 days showed decreased viability at all concentrations of the hormones with the greates reduction at $10^{-5} \mathrm{M}$.

Finally, for the control groups as well as the groups with individual and combined addition of hormones, cell viability was lower in the groups cultured for 14 days, compared to the groups cultured for 7 days.

\subsection{Effects of Culture Time and the P4, T, and E2 Hormones on Alkaline Phosphatase Activity}

The alkaline phosphatase activity changed according to the time during which the osteoblasts were cultured (Fig. 5). Higher alkaline phosphatase activity was observed for the group cultured for 7 days, compared to the groups cultured for 0 and 14 days.

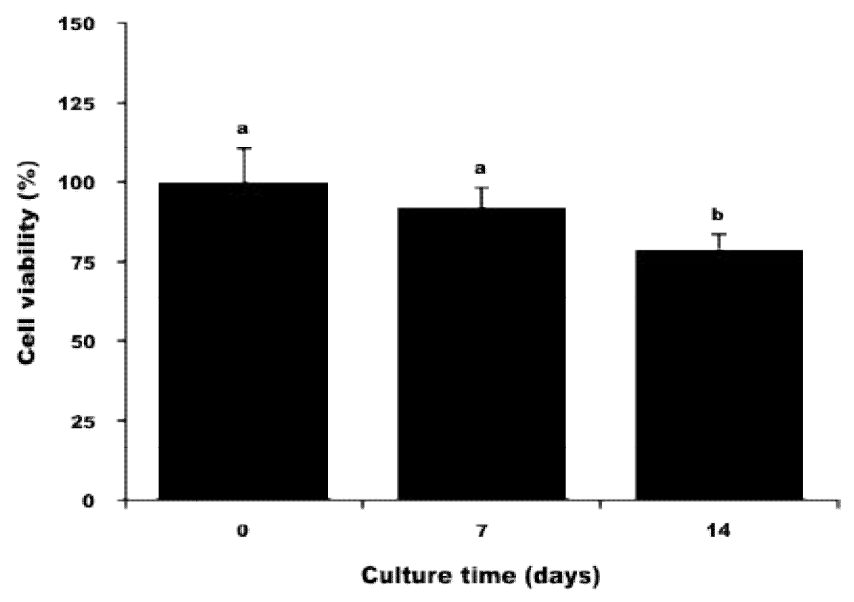

Fig. 3. Effects of culture time on viability of osteoblast cultured in osteogenic medium until 14 days

Results are represented as means + - SEM. ( $n=6$ independent cultures). Different superscript lowercase letters indicate differences among the times. $p<0.05$

(A)

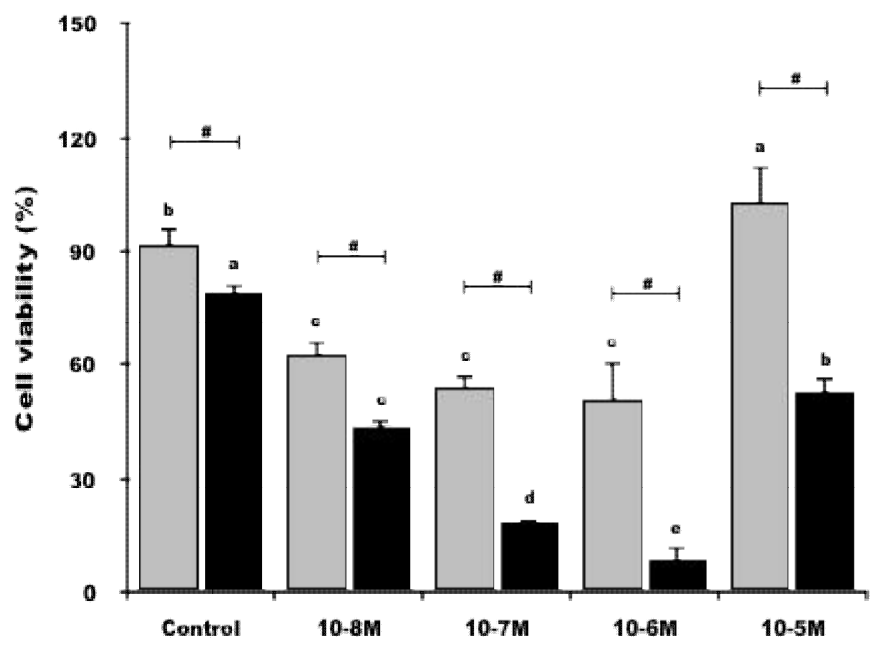


(B)

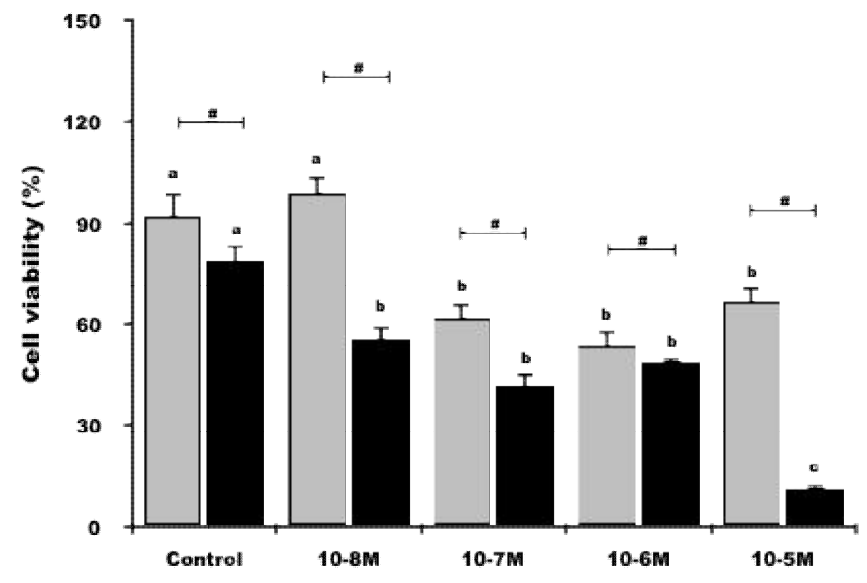

(C)

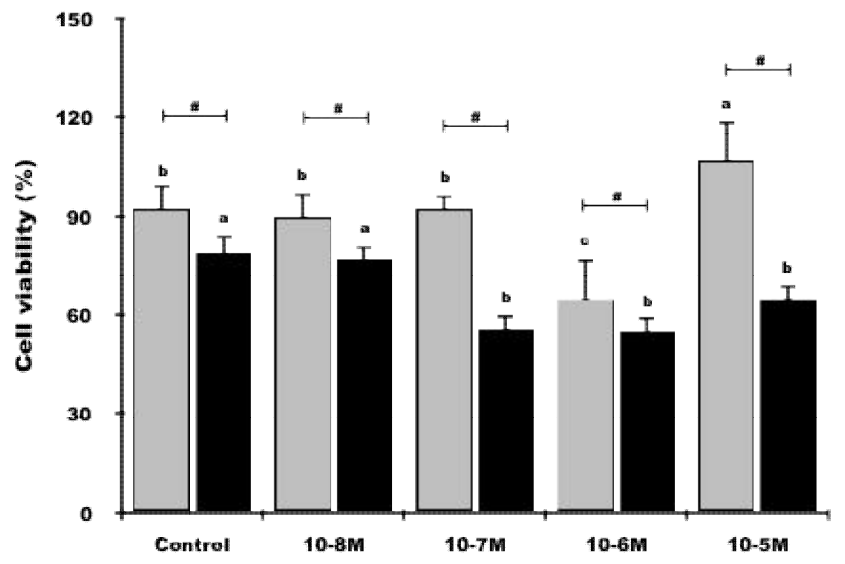

(D)

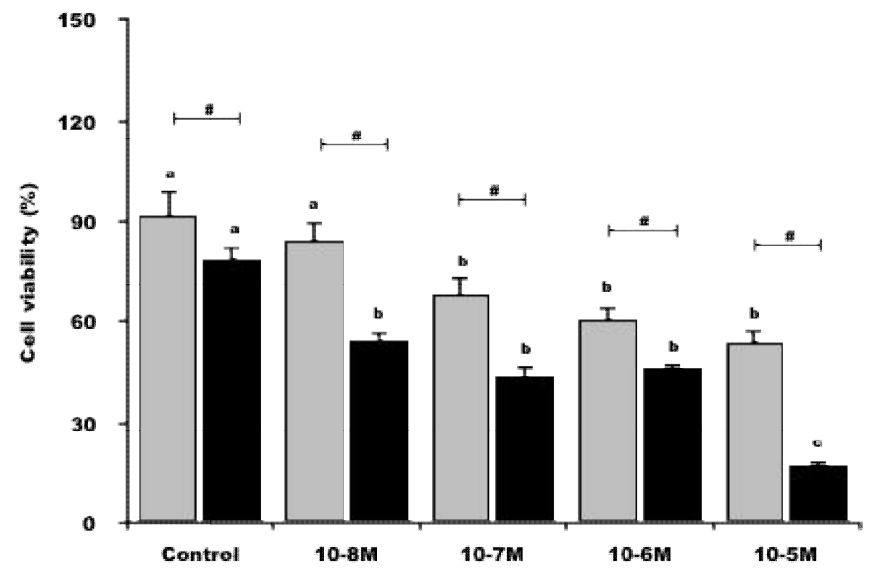

Fig. 4. Effects of different concentrations ( 0 (control), $10^{-8} \mathrm{M}, 10^{-7} \mathrm{M}, 10^{-6} \mathrm{M}$ and $10^{-5} \mathrm{M}$ ) of progesterone (A), testosterone (B), estradiol (C) and all hormones together (D) on viability of osteoblast cultured in osteogenic medium for 7 days (gray bars) and 14 days (black bars) Results are represented as means + - SEM. ( $n=6$ independent cultures). Different superscript lowercase letters indicate differences within the group among the concentrations; \# indicate differences among the groups. $p<0.05$ 


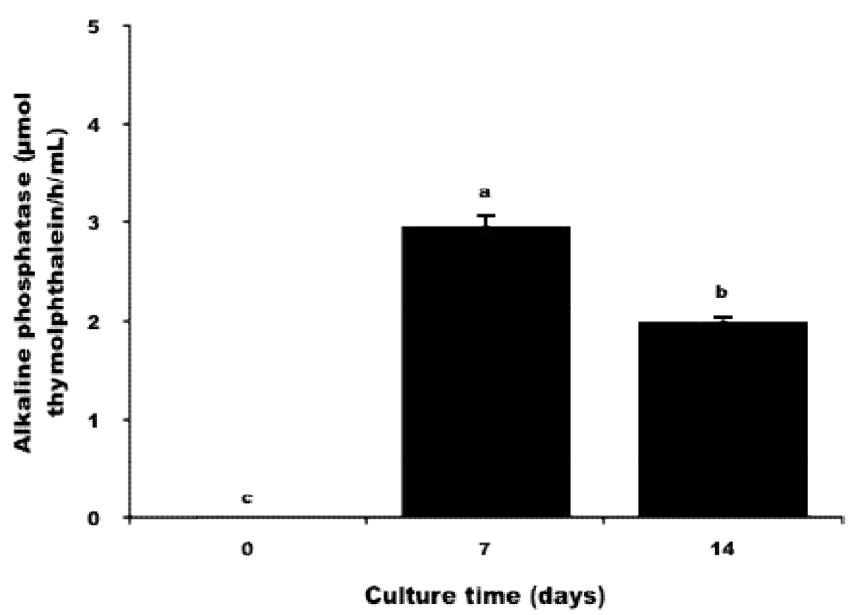

Fig. 5. Alkaline phosphatase activity in osteoblast cultured in osteogenic medium for 0,7 and 14 days

Results are represented as means + - SEM. ( $n=6$ independent cultures). Different superscript lowercase letters indicate differences among the times. $p<0.05$

The groups cultured for 7 and 14 days showed an influence of progesterone on the alkaline phosphatase activity (Fig. 6A). For osteoblasts cultured for 7 days, the lowest alkaline phosphatase activity was observed with $\mathrm{P} 4$ at a concentration of $10^{-7} \mathrm{M}$. When the cells were cultured for 14 days, the lowest alkaline phosphatase activity was observed for the cells cultured with P4 at a concentration of $10^{-8} \mathrm{M}$. In terms of the effect of culture time, the 7-day osteoblast cultures showed higher alkaline phosphatase activity than the 14-day cultures, both without P4 (control) and with P4 at all concentrations except $10^{-7} \mathrm{M}$.

For both culture times, the alkaline phosphatase activity was also influenced by testosterone (Fig. 6B). Testosterone concentrations of $10^{-8} \mathrm{M}$ and $10^{-6} \mathrm{M}$ increased phosphatase activity in the cells cultured for 7 days, while lower alkaline phosphatase activities were observed when $T$ was added at concentrations of $10^{-7} \mathrm{M}$ and $10^{-5}$ $M$. When the cells were cultured for 14 days, a $T$ concentration of $10^{-8} \mathrm{M}$ significantly decreased the alkaline phosphatase activity. In terms of the effect of the culture time, alkaline phosphatase activity was lower for the 14-day cultures, compared to the 7-day cultures.

The effect of E2 on alkaline phosphatase activity is shown in Fig. 6C. Lower phosphatase activity was observed when the cells were cultured for 7 days with E2 concentrations of $10^{-8} \mathrm{M}$ and $10^{-5}$ M. For cells cultured for 14 days, alkaline phosphatase activity was higher with E2 concentrations of $10^{-8} \mathrm{M}$ and $10^{-5} \mathrm{M}$. The alkaline phosphatase activity was higher for cells cultured for 7 days, compared to those cultured for 14 days.

Finally, the effects on alkaline phosphatase activity of adding all the hormones to the osteoblast cultures simultaneously are shown in Fig. 6D. For the 7-day cultures, lower alkaline phosphatase activity was observed for $10^{-8} \mathrm{M}$ concentration of the hormones. In the case of cells cultured for 14 days, the lowest alkaline phosphatase activity was observed using the hormones at concentrations of $10^{-8} \mathrm{M}$. The alkaline phosphatase activity was higher for cells cultured for 7 days, compared to those cultured for 14 days.

\subsection{Effects of Culture Time and the P4, T, and E2 Hormones on Biological Mineralization}

The osteoblasts cultured in osteogenic medium for 7 and 14 days showed mineralization of the extracellular matrix (Fig. 7). When progesterone was added to the medium, there were decreases in mineralization at progesterone concentrations of $10^{-8} \mathrm{M}, 10^{-7} \mathrm{M}$, and $10^{-6} \mathrm{M}$ (Fig. 8A), for both culture times, compared to the cultures without addition of progesterone.

All Tconcentrations used decreased mineralization of the extracellular matrix (Fig. 8B), irrespective of culture time, compared 
to the cultures without $T$. In cultures with testosterone at $10^{-8} \mathrm{M}$ and $10^{-6} \mathrm{M}$, greater

mineralization was observed for cells cultured for 14 days, compared to those cultured for 7 days.

(A)

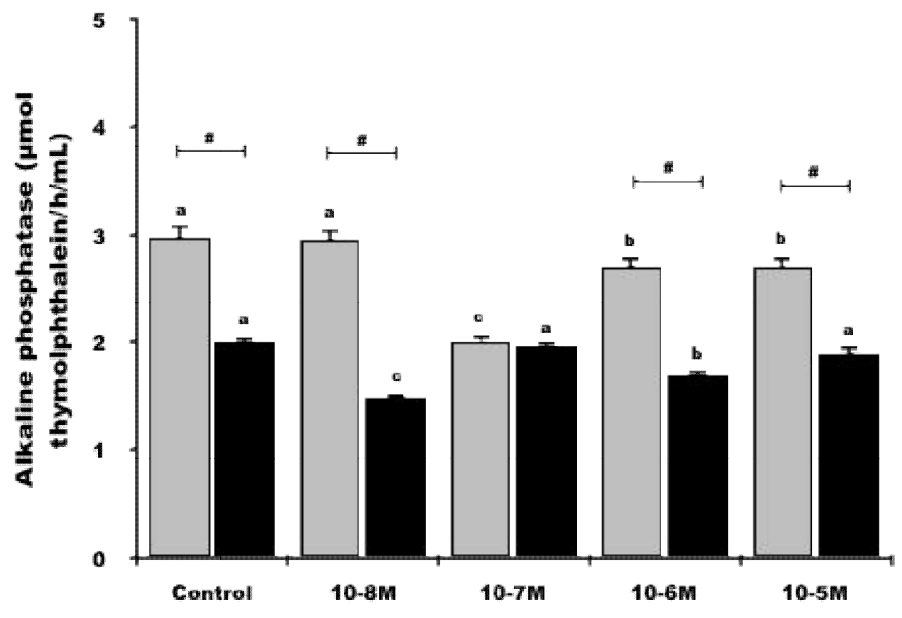

(B)

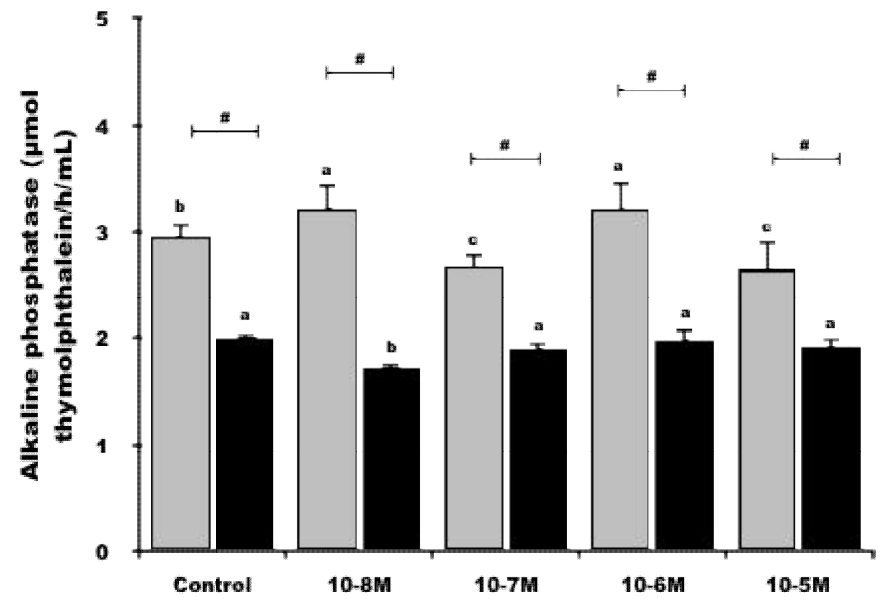

(C)

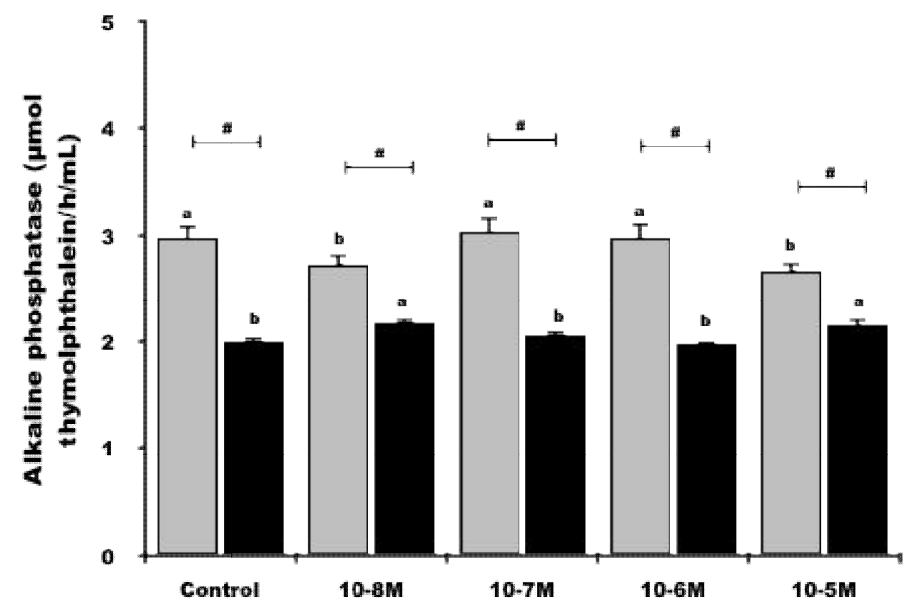


(D)

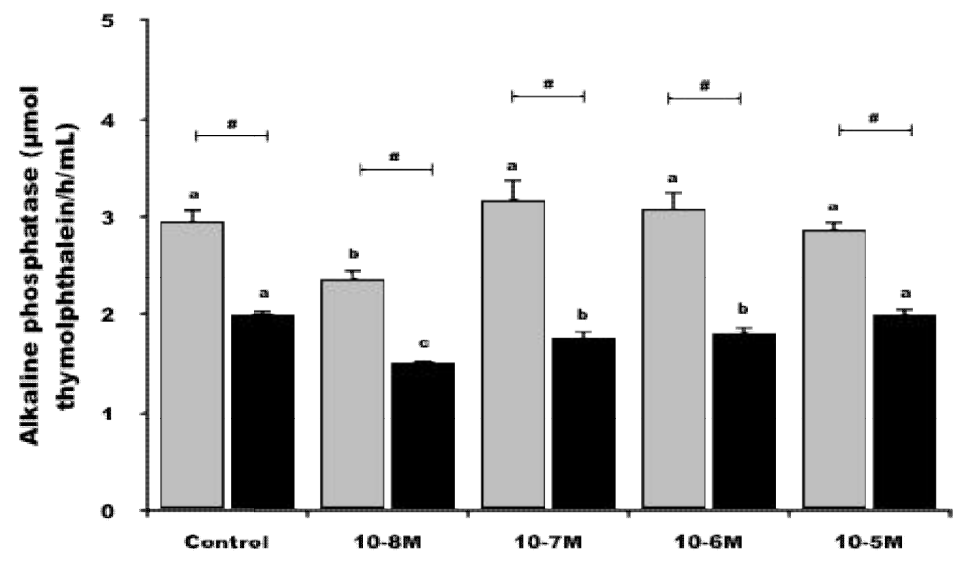

Fig. 6. Effects of different concentrations ( 0 (control), $10^{-8} \mathrm{M}, 10^{-7} \mathrm{M}, 10^{-6} \mathrm{M}$ and $10^{-5} \mathrm{M}$ ) of progesterone (A), testosterone (B), estradiol (C) and all hormones together (D) on alkaline phosphatase activity in osteoblast cultured in osteogenic medium for 7 days (gray bars) and 14 days (black bars)

Results are represented as means $+/-$ SEM. ( $n=6$ independent cultures). Different superscript lowercase letters indicate differences within the group among the concentrations; \# indicate differences among the groups. $p<0.05$

For cells cultured for 7 days, E2 concentrations of $10^{-8} \mathrm{M}, 10^{-6} \mathrm{M}$, and $10^{-5} \mathrm{M}$ decreased extracellular matrix mineralization, while the cells cultured for 14 days only showed decreased mineralization for E2 concentrations of $10^{-6} \mathrm{M}$ and $10^{-5} \mathrm{M}$ (Fig. 8C), compared to the control groups. Cells cultured with E2 at $10^{-8} \mathrm{M}$ showed higher mineralization in the 14-day culture, compared to the 7-day culture.

When all the hormones were added together to the media, the 7-day cultures showed decreased mineralization for hormone concentrations of $10^{-8}$ $\mathrm{M}, 10^{-7} \mathrm{M}$, and $10^{-6} \mathrm{M}$. The 14-day cultures showed increased in mineralization for $10^{-5} \mathrm{M}$ concentrations of the hormones, while decreased mineralization was observed for all other hormone concentrations (Fig. 8D). Finally, greater mineralization was observed for cells cultured for 14 days using the higher hormone concentrations $\left(10^{-6} \mathrm{M}\right.$ and $\left.10^{-5} \mathrm{M}\right)$, compared to those cultured for 7 days.

\section{DISCUSSION}

In studies involving the in vitro reproduction of biological conditions, cell culture experiments are used to assist in the development of models designed to elucidate the mechanisms of control of cell and tissue functions. However, it is not always possible to reproduce, in vitro, conditions identical to those present in the living organism, mainly due to the numerous unknown functional mechanisms that exist in vivo. Therefore, the results of in vitro experiments have to be analyzed in specific contexts. The results of this study showed that the OSTEO-1 cells remained viable for $72 \mathrm{~h}$ in culture and that the presence of $10 \%$ FBS increased the viability of these cells. This viability could be associated with potential increases of cell differentiation and bone formation. Fetal bovine serum is often added to culture media as a supplement, because it contains biological components such as fatty acids, growth factors, amino acids, vitamins, and hormones, which are required for cell cultures performed following certain experimental protocols [39]. Therefore, the use of FBS in culture media, despite being necessary for the cultivation of certain cell types, can affect experimental results related to cell maintenance, division, and differentiation $[40,41,42,43]$. Furthermore, the use of this supplement in culture media may compromise experimental results because it is a natural substance whose composition can vary between samples [44]. The presente findings demonstrated the influence of FBS on cellular responses, especially in terms of cell viability, in the absence or presence of the steroid hormones. It was also found that when the cells were differentiated in osteogenic medium, the hormones modulated cell viability, alkaline phosphatase activity, and mineralization of the extracellular matrix.

When the OSTEO-1 cells were cultured with P4, $\mathrm{T}$, and E2 (separately or in combination) in the absence and presence of serum, dual effects 
were observed that were dependent on the concentrations of the hormones and FBS. The addition of P4 to the osteogenic culture medium resulted in stimulatory and inhibitory effects on cell viability for both undifferentiated [45] and differentiated cells. Such responses could be governed by factors including cell differentiation, specific receptors, and steroid- receptor interactions. The components of FBS could influence these responses by interfering in hormone-receptor interactions and activating and/or inhibiting intracellular signaling pathways. Furthermore, P4 affected alkaline phosphatase activity and mineralization of the extracellular matrix, suggesting that progesterone modulated the differentiation and functional activity of osteoblasts cultured for 14 days. The effects of progesterone on bone metabolism are controversial [46]. It has been reported to prevent bone loss in pre- and perimenopausal women [15]. The use of E2 and P4 alone, at concentrations of $10^{-10} \mathrm{M}$, was found to stimulate DNA synthesis and the growth of osteoblasts, cultured for 1 day in serum-free medium [47]. Furthermore, the metabolization of P4 can generate active products that interact with $\mathrm{E} 2$ receptors and modulate bone cell activity [46].

In vitro studies have demonstrated that both $\mathrm{T}$ and dihydrotestosterone (DHT) modulate the proliferation of osteoblast progenitor cells in different species $[48,49,50,51]$. Controversial effects of these hormones include stimulation or inhibition (or neither) of alkaline phosphatase activity, type I collagen synthesis, synthesis and release of osteocalcin and mineralization of the extracellular matrix of bones [52,53]. In addition, androgens decrease apoptosis of osteoclasts and osteocytes [54]. Our results demonstrated that $\mathrm{T}$ influenced the viability of undifferentiated osteoblasts in a dose-dependent manner. Testosterone concentrations similar to physiological levels increased cell viability, while decreased viability was observed when concentrations were increased in order to mimic PCOS. These effects were consequences of direct and/or indirect interactions of $T$ with its receptors present in osteoblasts. Since the cells were not yet differentiated, it appeared that $\mathrm{T}$ was able to influence the dynamics of osteoblasts in vitro prior to differentiation. In addition, bone engagement could be initiated prior to differentiation of these cells, under conditions similar to PCOS, in which $\mathrm{T}$ concentrations are high. The results showed that when the cells became differentiated in an osteogenic medium, the highest concentration of $T\left(10^{-5} \mathrm{M}\right)$ decreased cell viability and mineralization of the extracellular matrix, but did not change the alkaline phosphatase activity. Therefore, the effects of high concentrations of $\mathrm{T}$ on osteoblasts cultured for 14 days were indicative of a reduction in osteoblastic activity and impaired bone formation in vitro.

Estradiol addition resulted in increased cell viability at a concentration of $10^{-6} \mathrm{M}$ and decreased cell viability at $10^{-5} \mathrm{M}$, suggesting that in the case of the model studied, estradiol had a stimulatory effect on cell viability, prior to differentiation. However, after differentiation of the cells in an osteogenic medium, a higher E2 concentration resulted in decreased cell viability, increased alkaline phosphatase activity, and decreased mineralization of the extracellular matrix. Therefore, estradiol modulated the activity of osteoblasts cultured for up to 14 days. Estrogens, especially 17 $\beta$-estradiol, are important for bone metabolism [55]. As women pass through menopause, E2 levels decrease and there is a reduction in bone mineral density [56]. The interaction of E2 with its receptors ERa and $E R \beta$, detected by immunohistochemistry in osteoblasts, osteocytes, and osteoclasts [57, 58], has protective effects on the bone due to a variety of mechanisms. These include inhibition of the activity of cytokines that stimulate osteoclast activity $[59,60]$, inhibition of the activity of nuclear factor $\mathrm{kB}(\mathrm{NF} K \mathrm{~B})$ that inhibits osteoblast activity by modulating osteoclast suppresion via the relationship with RANKL/osteoprotegerin (OPG) [57], and inhibition of osteoblast apoptosis [61]. Genetic studies using ERa knockout mice have identified reduced osteoblastogenesis and expression of osteocalcin [62]. ER $\beta$ knockout mice have shown increased trabecular bone, without any changes in the cortical bone [63].

The most interesting results in this study were obtained when all the steroid hormones were added together at higher concentrations $\left(10^{-5} \mathrm{M}\right)$. The lowest viability of the osteoblasts was observed under these conditions, in both the absence and presence of serum. The OSTEO-1 lineage is considered to be a pre-osteoblast cell line $[34,45]$, and it can be inferred that the exposure of these cells to high concentrations of P4, T, and E2 together, mimicking PCOS, may compromise cell differentiation and formation of the extracellular matrix for calcium deposition, hence lowering the quality of the bone tissue. When cells were differentiated in osteogenic 
medium, the combined hormones decreased cell viability in a dose-dependent manner, with the lowest viability of the osteoblasts being observed at the highest hormone concentration $\left(10^{-5} \mathrm{M}\right)$.

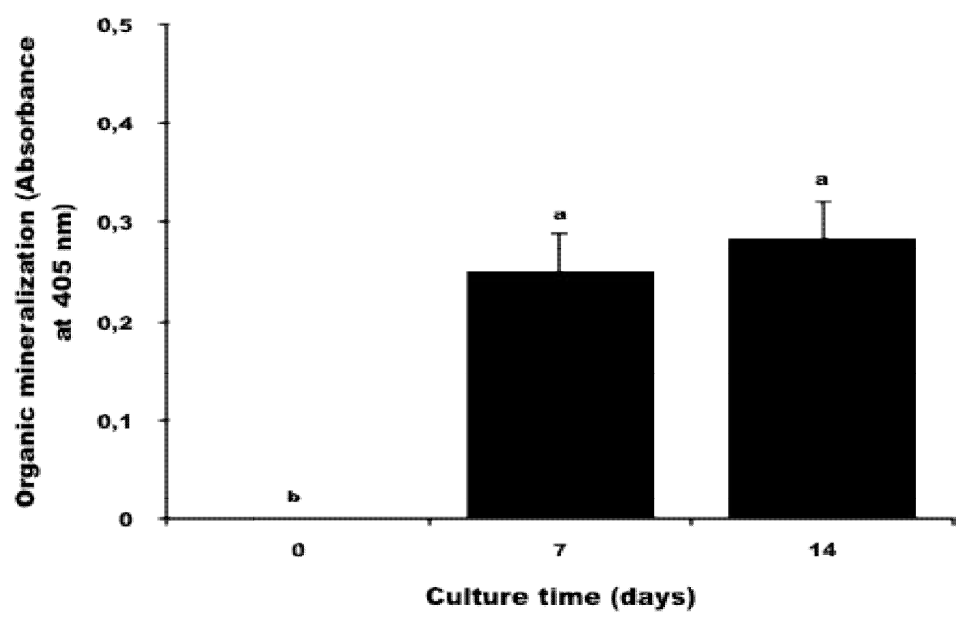

Fig. 7. Organic mineralization in osteoblast cultured in osteogenic medium for 0,7 and 14 days Results are represented as means + - SEM. ( $n=6$ independent cultures). Different superscript lowercase letters indicate differences among the times. $p<0.05$

(A)

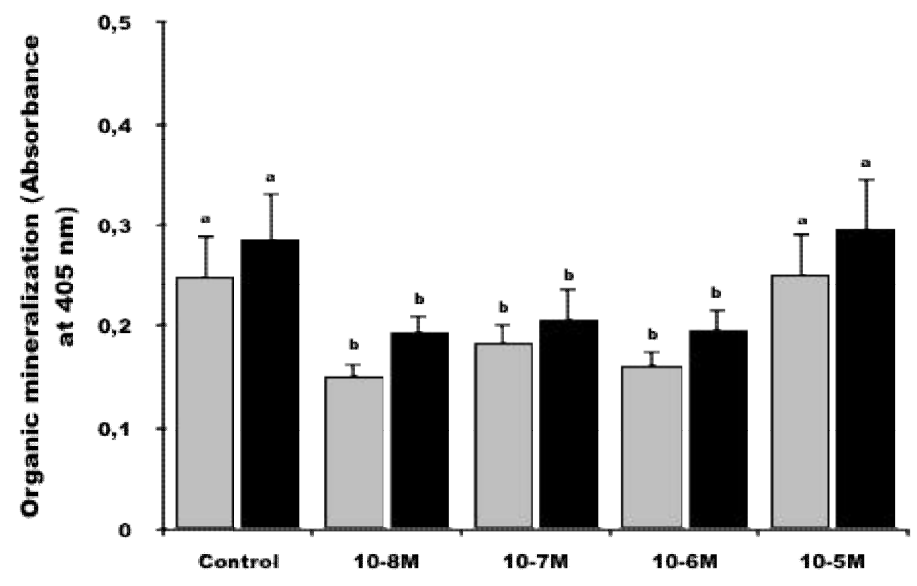

(B)

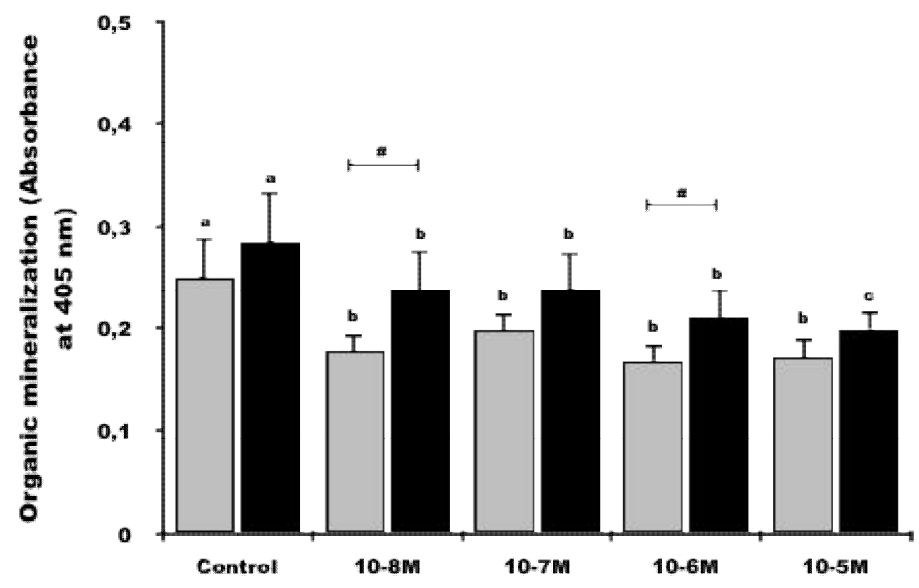


(C)

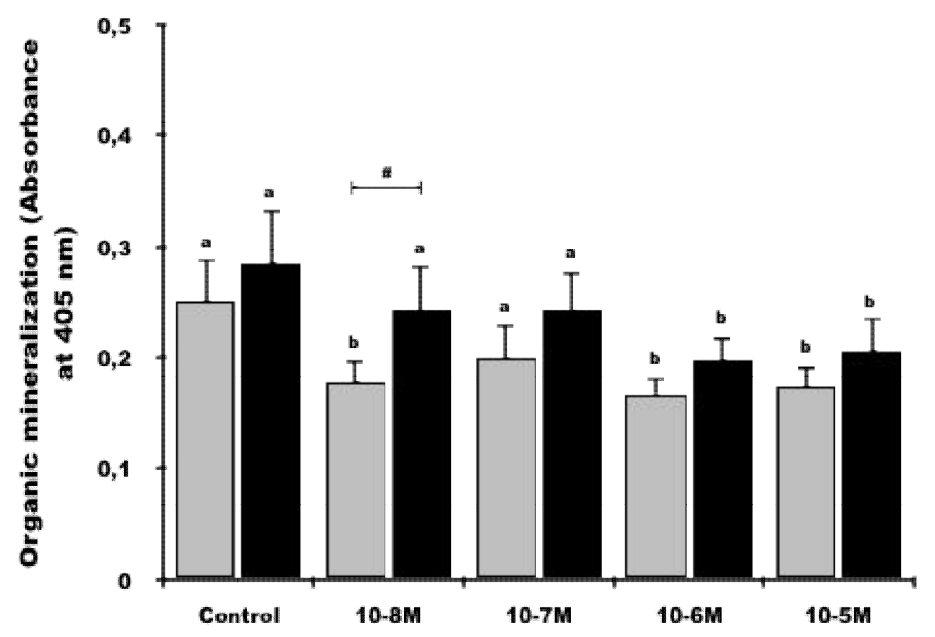

(D)

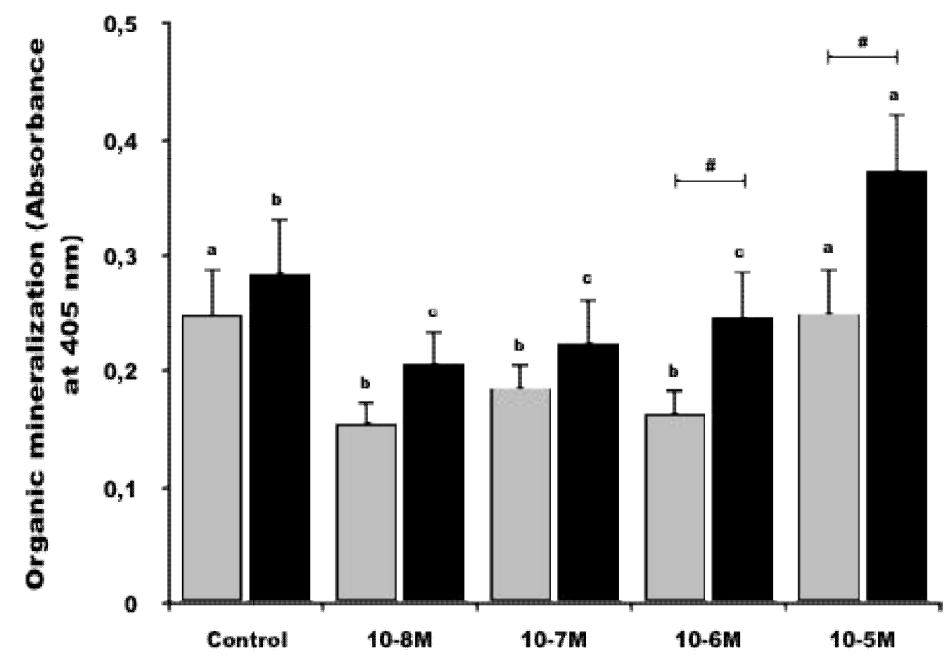

Fig. 8. Effects of different concentrations ( 0 (control), $10^{-8} \mathrm{M}, 10^{-7} \mathrm{M}, 10^{-6} \mathrm{M}$ and $10^{-5} \mathrm{M}$ ) of progesterone (A), testosterone (B), estradiol (C) and all hormones together (D) on organic mineralization in osteoblast cultured in osteogenic medium for 7 days (gray bars) and 14 days (black bars)

Results are represented as means + - SEM. ( $n=6$ independent cultures). Different superscript lowercase letters indicate differences within the group among the concentrations; \# indicate differences among the groups. $p<0.05$

However, at this concentration there were no changes in alkaline phosphatase activity, and there was an increase in bone mineralization after 14 days of culture. Therefore, higher concentrations of the combined hormones reduced the viability of osteoblasts and stimulated mineralization of the extracellular matrix. The sex hormone could have nongenomic effects on bone cell activity. Studies have shown anti-apoptotic effects of estrogens and androgens on osteoblasts cultured in vitro [64]. These hormones act in the development and maintenance of the skeleton in men and women. In both sexes, plasma levels of E2 and T decrease with age, contributing to reduced bone mass and increased risk of fractures [56]. The in vitro results obtained in this study demonstrated that ovarian steroids at concentrations mimicking those found in PCOS [33] modulated osteoblast viability and bone synthesis. We are unawared of any other in vitro studies that have mimicked the effects of ovarian steroids on the activity and viability of osteoblasts in a situation similar to PCOS. 


\section{CONCLUSION}

Taken together, the results demonstrated that the osteoblast culture model employed here enable evaluation on cell viability, alkaline phosphatase activity, mineralization of the extracellular matrix, together with the effects thereon of culture time, FBS, P4, T, and E2. Furthermore, according to studies in progress in our laboratory, this culture model can be used for in vitro studies of the effects of polycystic ovary syndrome on osteoblastic activities before and after cell differentiation. However, molecular and genomic studies are needed in order to identify the specific receptors and intracellular signaling pathways used by the ovarian steroids present in isolation and in combination. Additionally, studies using cell co-cultures are needed to elucidate the interactions among osteoblasts, adipocytes, and myocytes in metabolic and clinical situations similar to PCOS.

\section{ACKNOWLEDGEMENTS}

The authors thank Dr. Jorge Alberto Achcar for statistical analysis support and FUNADESP and CNPq for financial support.

\section{COMPETING INTERESTS}

Authors have declared that no competing interests exist.

\section{REFERENCES}

1. Deng $L$, Wang $Y$, Peng $Y$, Wu $Y$, Ding $Y$, Yuhail J, Shen Z, Fu Q. Osteoblast-derived microvesicles: A novel mechanism for communication between osteoblasts and osteoclasts. Bone. 2015;79:37-42.

2. Oldknow KJ, Macrae VE, Farquharson C. Endocrine role of bone: Recente and emerging perspectives beyond osteocalcin. J. Endocrinol. 2015;225(1): 1-19.

3. Tompkins KA. The osteoimmunology of alveolar bone loss. Conect. Tissue Res. 2016;57(2):69-90.

4. Kulak CAM, Dempster DW. Bone histomorphometric: A concise review for endocrinologists and clinicians. Arq. Bras. Endocrinol. Metab. 2010;54(2):87-98.

5. Tamma R, Zallone A. Osteoblast and osteoclast crosstalk: From OAF to ephrin. Inflammation \& Allergy - Drug Targets. 2012;11:196-200.
6. De Fusco C, Messina A, Monda V, Viggiano $E$, Moscatelli $F$, Valenzano $A$, Esposito T, Sergio C, Cibelli G, Monda M, Messina G. Osteopontin: Relation between adipose tissue and bone homesotasis. Stemm Cells International. 2017;4045238.

7. Balach J. Sex steroids and bone: Current perspectives. Hum. Reprod. Update. 2003; 3:201-222.

8. Castelo-Branco C, Gómez O, Pons F, Martinez de Osaba MJ, Balasch J, Vanrell JA. Secreting ovarian tumors may protect women from osteoporosis. Gynecol. Oncol. 2003;88:149-152.

9. Gregouriou O, Kouskouni E, Bakas P, Konidaris S, Papadias K, Kalovidouris A, Creatsas G. Bone mineral density in women with idiopatichirsutim. Gynecol. Endocrinol. 2000;14:364-368.

10. Zborowki JV, Cauley JA, Talbott EO, Guzick DS, Winters SJ. Bone mineral density, adrogens and the polycystic ovary: the complex and controversial issue and androgenic influence in female bone. J. Clin. Endocrinol. Metab. 2000;67:937943.

11. Oliveira FDR, Rezende MB, Faria NF, Dias TRG, Oliveira WCSD, Rocha ALL, Cândido AL. Association between lipid accumulation product and hirsutism in pacientes with polycystic ovary syndrome. Rev. Bras. Ginecol. Obst. 2016;38(2):7176.

12. Villiers TJ. The role of menopausal hormone therapy in the management of osteoporosis. Climacteric. 2015;1-3.

13. Manolagas SC, Kousteni S, Jilka RL. Sex steroids and bone. Recent Prog. Horm. Res. 2002;57:385-409.

14. Slootweg MC, Ederveen AGH, Schot LPC, Schoonen WGEJ, Kloosterboer HJ. Oestrogen and progestogen synergistically stimumlates human and rat osteoblast proliferation. J. Endocrinol. 1992;133:R5R8.

15. Seifer-Klauss V, Prior JC. Progesterone and bone: Actions promoting bone health in women. J. Osteop. 2010;1-18.

16. Dumitrescu R, Mehedintu C, Briceag I, Purcarea VL, Hudita D. The polycystic ovary syndrome: An update on metabolic and hormonal mechanisms. J. Med. Life. 2015;8(2):142-145.

17. Spritzer PP, Lecke SB, Satler F, Morsch DM. Adipose tissue dysfunction, adipokines, and low-grande chronic 
inflammation in polycystic ovary syndrome. Reproduction. 2015;149(5):R219-R227.

18. Pandey V, Singh A, Singh A, Krishna A, Pandey U, Tripathi YB. Role of oxidative stress and low-grade inflammation in letrozole-induced polycystic ovary syndrome in the rat. Reprod. Biol. 2016; 16(1):70-77.

19. Wu C, Lin F, Qiu S, Jiang Z. The characterization of obese polycystic ovary syndrome rat model suitable for exercise intervention. PLoS ONE. 2014;9(6): e99155.

20. Wu H, Yu K, Yang Z. Association between TNF-alpha and interleukin gene polymorphisms with polycystic ovary syndrome risks: A systematic review and meta-analysis. J. Assist. Reprod. Genet. 2015;32(4):645-652.

21. Barber TM, Franks S. Adipocyte biology in polycystic ovary syndrome. Mol. Cell Endocrinol. 2013;373(1-2):68-76.

22. Garg D, Merhi Z. Advanced glycation end products: Link between diet and ovulatory dysfunction in PCOS? Nutrients. 2015; 7:10129-10144.

23. Seow KM, Lin $\mathrm{YH}$, Hwang JL, Wang $\mathrm{PH}$, Ho LT, Lin YH, Juan CC. Expression level of heam oxygenase-I in the ometal adipose tissue and peripheral blood mononuclear cells of women with polycystic ovary syndrome. Hum. Reprod. 2011;26(2):431-437.

24. Panico A, Messina G. Lupoli GA, Lupoli R, Cacciapuoti M, Moscatelli $F$, Esposito $T$, Villano I, Valenzano, A, Monda V, Messina A, Precenzano F, Cibelli G, Monda M, Lupoli G. Quality of live in overweight (obese) and normal-weight women with polycystic ovary syndrome. Patient Prefer Adherence. 2017;11:423-429.

25. Polotsky AJ, Allshouse AA, Crawford SL, Harlow SD, Khalil N, Kazlauskatie R, Santoro N, Legro S. Hyperandrogenic oligomenorrhea and metabolic risks across menopausal transition. J. Clin. Endocrinol. Metab. 2014;99(6):2120-2127.

26. Palomba S, Santagni S, Falbo A, La Sala GB. Complications and challenges associated with polycystic ovary syndrome: Current perspectives. Inter. J. Women's Health. 2015;7:745-763.

27. Hoeger KM, Kochman L, Wixom N, Craig K, Miller RK, Guzick DS. A randomized, 48-week, placebo-controlled trial of intensive lifestyle modification and/or metformin therapy in overweight women with polycystic ovary syndrome: A pilot sutdy. Fertil. Steril. 2004;82(2):421-429.

28. Bruner B, Chad K, Chize D. Effects of exercise and nutritional counseling in women with polycystic ovary syndrome. Appl. Physiol. Nutr. Metab. 2006;31(4): 384-391.

29. Norman RJ, Davies MJ, Lord J, Moran LJ. The role of lifestyle modification in polycystic ovary syndrome. Trends Endocrinol. Metab. 2002;13(6):251-257.

30. Eshre Rotterdam workshop group. Revised 2003 consensus on diagnostic criteria and long term health risks related to polycystic ovary syndrome (PCOS). Hum. Reprod. 2004;19(1):41-47.

31. Palomba $S$, Giallauria $F$, Falbo A, Russo $\mathrm{T}$, Oppedinaso R, Tolino A, Colao A, Vigorito $C$, Zullo $F$, Orio F. Structured exercise training programm versus hypocaloric hyperproteic diet in obese polycystic ovary syndrome patients with anovulatory infertility: A 24-week pilot study. Hum. Reprod. 2008;23(3):642-650.

32. Rossler KK, Birkebaek C, Ravn P, Andersen MS, Glintborg D. Effects of exercise and group counselling on body composition and VO2max in overweight women with polycystic ovary syndrome. Acta Obstetr. Gynecol. Scand. 2013;92: 272-277.

33. Montrezor LH, Carvalho D, Dias MB, Anselmo-Franci JA, Bícego KC, Gargaglioni LH. Hypoxic and Hypercapnic ventilatory responses in rat with polycystic ovaries. Resp. Physiol. Neurobiol. 2015; 217:17-24.

34. Togashi AY, Cirano FR, Marques MM, Pustiglioni FE, Alves de Lima LAP. Characterization of bone cells obtained from the calvaria of neonatal rats (OSTEO-1) after serial subculture. J. Appl. Oral Sci. 2007; 15(5):442-447.

35. Brancaglião LFC, Gonçalves VM, Lemos JES, Rocha NF, Aquino R, Amaral AC, Montrezor LH. In vitro effects of FBS and ovarian steroids on osteoblast viability. FASEB J. 2015;29(Suppl):685.9.

36. Maniatopoulos C, Sodek J, Melcher AH . Bone formation in vitro by stromal cells obtained from bone marrow of young adult rats. Cell Tissue Res. 1988;254(2):317330.

37. Mosmann T. Rapid colorimetric assay for cellular growth and survival: Application to 
proliferation and cytotoxicity assays. J. Immunol. Methods. 1983;65(1-2):55-63.

38. Gregory CA, Gunn WG, Peister A, Prockop DJ. An alizarin red-based assay of mineralization by adherent cells in culture: Comparison with cetylpyridinium chloride extraction. Anal. Biochem. 2004;329:77-84.

39. Faria AN, Zancanela DC, Ramos AP, Torqueti MR, Ciancaglini $P$. Estrogen and phenol red free mdium for osteoblast culture: Study of mineralization ability. Cytotechnology. 2015;67:1-10.

40. Mavrapoulos E, Hausen M, Costa AM, Alves G, Mello A, Ospina CA, Mir M, Granjeiro JM, Rossi AM. The impact of RGD peptide on osteoblast adhesion and spreading on zinc-substitute dihydroxyapatite surface. J. Mater. Sci. Mater. Med. 2013;24:1271-1283.

41. Montrezor LH, Piccinato CA, Collares CVA, Vireque AA, Rosa e Silva AAM. Comparision on medium supplementation on proliferation and hormone production by bovine granulosa cells in a defined culture system. J. Sci. Res. Report. 2014;3(5): 645-659.

42. Montrezor LH, Piccinato CA, Collares CVA, Vireque AA, Rosa e Silva AAM. Effects of angiotensin II, atrial natriuretic peptide and endothelin-1 on proliferation and steroidogenic output of bovine granulosa cells cultured in a chemically defined system. An. Reprod. Sci. 2015; 152:8-16.

43. Di Bernardo G, Messina G, Capasso S, Del Gaudio S, Cipollaro M, Peluso G, Casale F, Monda M, Galderisi U. Sera of overweight people promote in vitro adipocyte differentiation of boné marrow stroma cells. Stem Cell Research \& Therapy. 2017;5(1):4.

44. Kalbacova M, Broz A, Kalbac M. Influence of fetal bovine sérum proteins on the growth of human osteoblast cells on graphene. J. Biomed. Mater. Res. 2012; 100A:3001-3007.

45. Raisz LG. Pathogenesis of osteoporosis: Concepts, conflicts and prospects. J. Clin. Invest. 2005;115:3318-3325.

46. Quinkler M, Kaur K, Hewison M, Stewart PM, Cooper MS. Progesterone is extensively metabolized in osteoblasts: implication for progesterone actions on bone. Horm. Metab. Res. 2008;40(10): 479-484.
47. Scheven BAA, Damen CA, Hamilton NJ, Verhaar HJJ, Duursma SA. Stimulatory effects of estrogen and progesterone on proliferation and differentiation of normal human osteoblast-like cells in vitro. Biochem. Biophys. Res. Com. 1992;186: 54-60.

48. Bord S, Ireland DC, Beavan SR, Compston JE. The effects of estrogen on osteoprotegerin, RANKL, and estrogen receptor expression in human osteoblasts. Bone. 2003;32(2):136-141.

49. Hofbauer LC, Hicok KC, Khosla S. Effects of gonadal and adrenal androgens in a novel androgen-responsive human osteoblastic cell line. J. Cell Biochem. 1998;71:96-108.

50. Masuyama A, Ouchi $Y$, Sato F, Hosoi T, Nakamura T, Orimo H. Characteristics of steroid hormone receptors in cultured MC3T3-E1 osteoblastic cells and effect of steroid hormones on cell proliferation. Calcif. Tissue Int. 1992;51:376-381.

51. Nakano $Y$, Morimoto I, Ishida O, Fujihira T, Mizokami A, Tanimoto A, Yanagihara N, Izumi $\mathrm{F}$, Eto $\mathrm{S}$. The receptor, metabolism and effects of androgen in osteoblastic MC3T3-E1 cells. Bone Miner. 1994;26: 245-259.

52. Kapur SP, Reddi AH. Influence of testosterone and dihydrotestosterone on bone-matrix induced endochondral bone formation. Calcif. Tissue Int. 1989;44:108113.

53. Takeuchi M, Kakushi $H$, Tohkin M. Androgens directly stimulate mineralization and increase androgen receptors in human osteoblast-like osteosarcoma cells. Biochem. Biophys. Res. Commun. 1994; 204:905-911.

54. Kousteni S, Han L, Chen JR, Almeida M, Plotkin LI, Bellido T, Manolagas SC. Kinase-mediated regulation of common transcription factors accounts for the boneprotective effects of sex steroids. J. Clin. Invest. 2003;111:1651-1664.

55. Khalid AB, Krum SA. Estrogen receptors alpha and beta in bone. Bone. 2016; 87:130-135.

56. Cauley JA. Estrogen and bone health in men and women. Steroids. 2015;99:11-15.

57. Bord S, Ireland DC, Beavan SR, Compston JE. The effects of estrogen on osteoprotegerin, RANKL, and estrogen receptor expression in human osteoblasts. Bone. 2003;32(2):136-141. 
58. Souza MD, Sasso-Cerri E, Cerri PS. Immunohistochemical detection of estrogen receptor beta in alveolar bone cells of estradiol-treated female rats: possible direct action of estrogen on osteoclast life spain. J. Anat. 2009;215(6): 673-681.

59. Pacifici R, Rifas L, McCracken R, Vered I, McMurtry C, Avioli LV, Peck WA. Ovarian steroid treatment blocks a postmenopausal increase in blood monocyte interleukin 1 release. Proc. Natl. Acad. Sci. U.S.A. 1989;86(7):2389-2402.

60. Weitzmann MN, Roggia C, Toraldo C, Weitzmann L, Pacifini R. Increased osteoclast development after estrogen loss: Medeiation by interleukin-6. Science. 1992;257(5066):88-91.

61. Kousteni S, Bellido T, Plotkin LI, O’Brien CA, Bodenner DL, Han L, Han K, DiGregorio GD, Katzenellenbogen JA, Katzenellenbogen BS, Roberson PK,
Weinstein RS, Jilka RL, Manolagas SC. Nongenotropic, sex-nonspecific signaling through the estrogen or androgen receptors: Dissociation from transcriptional activity. Cell. 2001;104(5):719-730.

62. Kim SW, Pajevic PD, Selig M, Barry KJ, YangJ Y, Shin CS, Baek, J-E. Kim WY, Kronenberg HM. Intermittent parathyroid hormone administration converts quiescente lining cells to active osteoblast. J. Bone Miner. Res. 2012;27(10):20752084.

63. Windahl $\mathrm{SH}$, Holberg $\mathrm{K}$, Vidal $\mathrm{O}$, Gustafsson JA, Ohlsson C, Andersson G. Female estrogen receptor beta -/- mice are pratically protected against age-related trabecular bone loss. J. Bone Miner. Res 2001;16(8):1388-1398.

64. Khosla S, Oursler MJ, Monroe DJ. Estrogen and the skeleton. Trends Endocrinol. Metab. 2012;23(11):576-581.

(c) 2017 Brancaglião et al.; This is an Open Access article distributed under the terms of the Creative Commons Attribution License (http://creativecommons.org/licenses/by/4.0), which permits unrestricted use, distribution, and reproduction in any medium, provided the original work is properly cited. http://sciencedomain.org/review-history/19242 